\title{
CORREDOR DE INFRAESTRUTURA VERDE: ROTA CICLOVIÁRIA COMO CONEXÃO ENTRE PARQUE DO POVO - IBIRAPUERA
}

\author{
GREEN INFRASTRUCTURE CORRIDOR: BICYCLE ROUTE AS CONNECTION \\ BETWEEN PARKS DO POVO AND IBIRAPUERA
}

\author{
Cíntia Miva Maruyama \\ Arquiteta e urbanista pela FAU/USP, Mestre em Engenharia Urbana, docente da UFPR/CEM \\ e-mail: cintiamaruyama@ufpr.br \\ Laís Padilha Leite \\ Arquiteta e urbanista pela UEMA, aluna especial da Pós - Graduação da FAU USP \\ e-mail: laispadilhaleite@gmail.com \\ Lívia Borges Dualibe de Deus \\ Arquiteta e urbanista pela UEMA, aluna especial da Pós - Graduação da FAU USP \\ e-mail: liviabd@gmail.com
}

\begin{abstract}
RESUMO
A Infraestrutura Verde é uma alternativa para cidades com urbanização tradicional, dentre todos os benefícios, essa abordagem de planejamento trata da inserção de transportes modais não motorizados. A hipótese da presente pesquisa baseou-se na possibilidade de implantação da Infraestrutura Verde, no município de São Paulo, em uma rota cicloviária que interligasse os Parque do Povo ao Ibirapuera com as devidas adequações. Tratou-se de um trabalho quali-quantitativo onde se identificou a infraestrutura existente e foram elaboradas propostas baseadas nos conceitos estudados. $O$ método da pesquisa discorreu sobre parâmetros de segurança viária com contagem veicular e diferença da velocidade entre automóvel e bicicleta. Dentre os resultados, destacou-se a necessidade de melhoria da arborização, implantação de ciclovias em trechos onde há ciclofaixa operacional, introdução de canteiros pluviais e biovaletas. Concluiu-se ainda ser desejável expandir as larguras de calçadas e ciclovias existentes de várias vias.
\end{abstract}

Palavras-chave: Infraestrutura Verde; ciclovia; melhores práticas de manejo das águas da chuva; arborização; segurança viária. 


\begin{abstract}
The Green Infrastructure is an alternative to cities with traditional urbanization. Among all the benefits, this planning approach deals with the insertion of non-motorized transportation means. The hypothesis taken for the present analysis was based on the possibility of implementation, with the necessary adaptions, of a Green Infrastructure of a cycling route that could interconnect Parque do Povo to Parque do Ibirapuera, in São Paulo City. It was a qualitative-quantitative work where the existing infrastructure was identified and proposals based on the concepts studied were drawn up. The research method analyzed road safety parameters with vehicles counting and the speed difference between cars and bicycles. Among the results, it was highlighted the need to improve the urban afforestation, implantation of bicycle paths in stretches where exists just operational paths, the introduction of rain beds and bio-ditches. It was also concluded that would be desirable to expand the widths of existing sidewalks and bicycle paths.
\end{abstract}

Keywords: green infrastructure; bicycle path; best practices for rainwater management; urban afforestation; road safety.

\title{
INTRODUÇÃO
}

As soluções tradicionais higienistas de drenagem são adotadas em grande parte das cidades brasileiras, trazendo dentre as diversas consequências aceleração no volume de escoamento superficial, aumento da duração e da frequência de ocorrência de alagamentos e inundações (TUCCl; ORSINI, 2005). Na busca de soluções para diminuir uma parte das deficiências observadas pelos sistemas higienistas foram desenvolvidas as MPM - Melhores Práticas de Manejo (Best Management Practices) das águas pluviais, como as técnicas de LID - Low Impact Development, uma abordagem alternativa para tratar os problemas relacionados às quantidades e qualidade dos escoamentos superficiais e procurar reduzir os impactos das urbanizações (CITY OF PORTLAND, 2016).

Desponta atualmente uma nova abordagem de planejamento para as cidades, a Infraestrutura Verde (IV) urbana. A IV se alinha com os objetivos das MPM, pois possui como um dos seus serviços ecológicos os relacionados ao manejo da água da chuva, 
procurando diminuir os escoamentos superficiais e o impacto das áreas urbanizadas. Cabe ressaltar que a IV se preocupa com outras questões, como favorecer os modais não motorizados, prover habitat para a biodiversidade, criar espaços abertos para convívio e recreação da comunidade (HERZOG, 2010).

Neste contexto, cabe considerar que o sistema viário ocupa pelo menos vinte por cento de uma área urbana, trata-se de espaço público de excelente potencial para receber elementos de drenagem que dão suporte à IV, como tipologias de melhores práticas de manejo das águas da chuva, floresta urbana e pavimentos permeáveis.

Também no contexto atual as mudanças climáticas impõem desafios às urbes, há previsões de que a região onde se enquadra o Estado de São Paulo possui a propensão ao aumento de calor e aos eventos intensos de chuva (SKANSI et al. 2013). O município de São Paulo é altamente urbanizado e já é constantemente atingido por enchentes e alagamentos. Deste modo este estudo visa contribuir na busca de soluções para a mitigação destes problemas.

Por outro lado o modal cicloviário não é poluente, possui baixo custo e é acessível a uma parcela grande da população, além de ser uma opção importante para cidades mais sustentáveis. Assim a pesquisa se situou na região Oeste e Centro Sul do município de São Paulo (Figura 1), a qual apresenta importantes polos geradores de viagens tanto com objetivos de lazer, como de trabalho. $O$ destaque ao lazer por possuir dois importantes parques, o do Povo e do Ibirapuera; o trabalho por abrigar usos comerciais e de serviços importantes como torres empresariais, shopping center entre outros. O estudo envolveu a conexão cicloviária entre os dois parques, pois tal modal é desejável para uma melhor qualidade de vida nas cidades de forma geral. Existe na área de estudo uma rota cicloviária delimitada pela Companhia de Engenharia de Tráfego de São Paulo denominada: "Ciclofaixa operacional de Lazer Zona Sul e Zona Oeste - Ligação entre Parques". Tal rota interliga os parques do Povo e do Ibirapuera e proporciona uma alternativa de lazer aos domingos e feriados e também foi objeto de análise. 


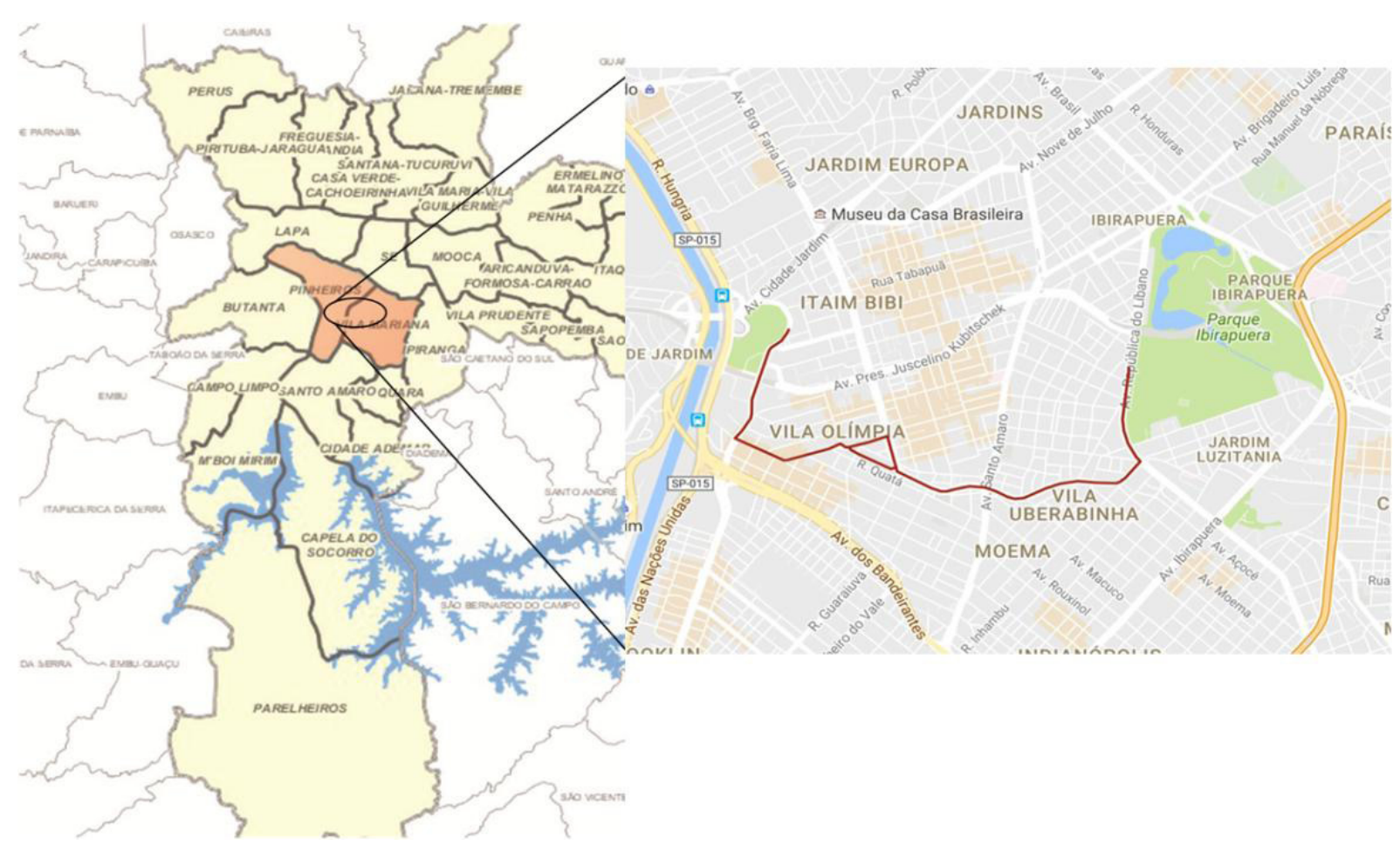

Figura 1 - Localização da área do estudo. Fonte: Geo Sampa e Google Maps, modificado pelas autoras (2016)

Assim foi elaborada uma pesquisa quali-quantitativa, cujos objetivos foram identificar e analisar a infraestrutura existente de ciclovias, calçadas, vias, arborização e segurança viária. Além disso, foi necessário analisar as bacias hidrográficas na área de estudo e por fim foram elaboradas propostas e diretrizes baseadas no conceito de Infraestrutura Verde.

\section{Sobre os conceitos de Infraestrutura Verde}

Para Ahern (2011), a Infraestrutura Verde é entendida como uma rede interconectada de áreas naturais protegidas, paisagens artificiais e híbridas. Esta hibridação própria da IV assegura a biodiversidade frente à ação antrópica, o que pode gerar múltiplos serviços ecológicos e funcionais ao público, tendo como princípio a sustentabilidade. $\mathrm{O}$ recorte da área de estudo abrangeu duas áreas verdes importantes para a capital paulista. Serão abordados a seguir os principais artifícios de IV com potenciais de reforçar a conexão física e natural entre estes dois parques, dentre esses artifícios estão: infraestrutura cicloviária, tipologias de melhores práticas de manejo e arborização urbana. 


\section{Infraestrutura Cicloviária}

Para a Associação Nacional dos Transportes Públicos - ANTP (2007) os espaços cicloviários podem ser separados em três categorias: os compartilhados, os parcialmente segregados e os totalmente segregados. O espaço compartilhado caracteriza-se pela via de tráfego sem adequação para o ciclista, sendo apenas mais largo que o normal, já o parcialmente segregado possui ciclofaixa na faixa de rolamento ou na calçada. $O$ terceiro caso é a ciclovia que caracteriza o espaço cicloviário totalmente segregado com diferença de nível da faixa de rolamento. Nesta situação a ciclovia pode existir na calçada ou no canteiro central.

Nos casos de compartilhamento de espaço, a rede pode ser de vias adaptadas ou não ao tráfego de bicicletas. Nessa alternativa, a circulação é feita em vias de baixo tráfego motorizado e com alto nível de segurança. Quando situadas no bordo da pista e no mesmo sentido dos veículos, a largura interna da ciclofaixa é de 1,20m com pintura separadora mínima de 0,40m e ideal de 0,60m. Deve haver faixa separadora da ciclofaixa com o meio fio de $0,20 \mathrm{~m}$. Então a largura total da ciclofaixa fica entre $1,80 \mathrm{~m}$ a 2,00 m (Figura 2).

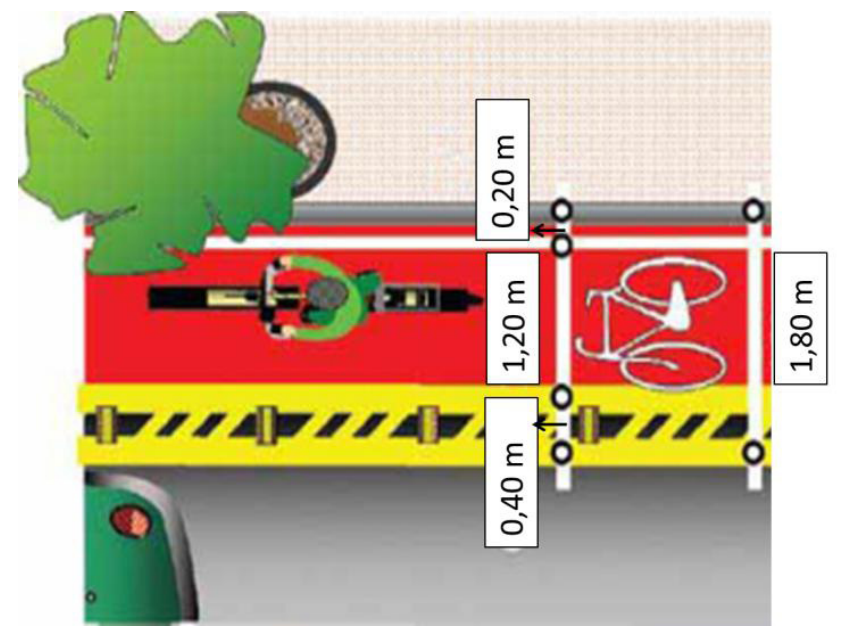

Figura 2 - Largura da ciclofaixa. Fonte: Ministério das Cidades (2007)
Ciclofaixas em calçada ou em canteiro podem ter largura total de $1,20 \mathrm{~m}$, com a pintura separadora feita na sua largura útil. Assim neste caso a largura livre para o ciclista é de $1 \mathrm{~m}$. Já a ciclovia é a infraestrutura que promove maior segurança ao ciclista por ter total segregação entre veículos e pedestres.

É um espaço com separação da faixa de veículos com desnível mínimo de $0,20 \mathrm{~m}$ geralmente mais alto que a faixa de rolamento e pode ser uni ou bidirecionais. Ciclovia bidirecional tem largura mínima de $2,50 \mathrm{~m}$, mais $0,60 \mathrm{~m}$ para calçada separadora e 0,75 m se a separação abrigar vegetação. Então a largura total da ciclovia é de 3,10m a 3,25m (GEIPOT, 2001; GONDIN, 2010). 

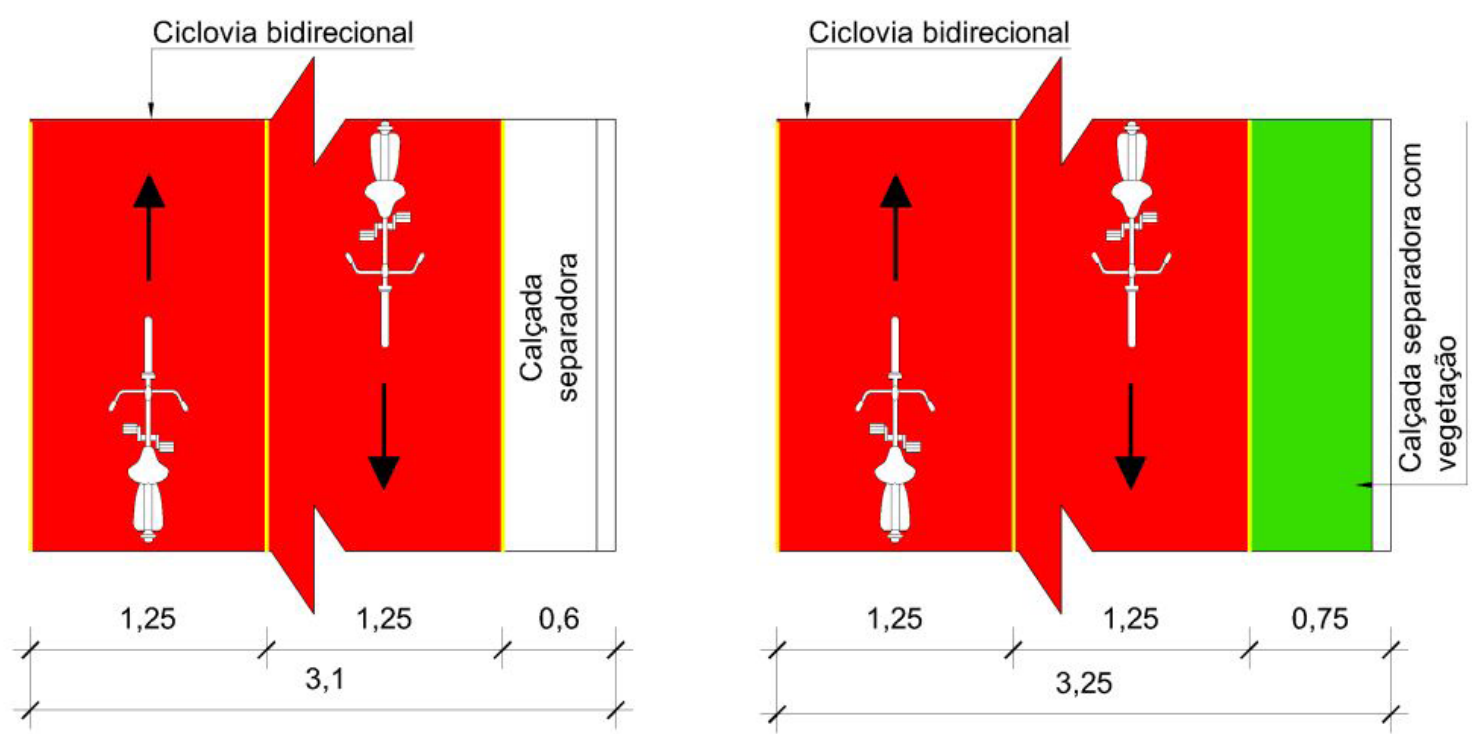

Figura 3 - Dimensões de ciclovias bidirecionais. Fonte: Gondin, 2010, adaptado pelas autoras

\section{Tipologias de Melhores Práticas de Manejo (MPM) água de chuva}

Tal como indicado na introdução, as MPM foram desenvolvidas para mitigar uma parte das problemáticas observadas na aplicação dos sistemas tradicionais de drenagem urbana. As MPM aliadas a técnicas como o LID enfatizam a conservação das características das paisagens naturais nas cidades (MOURA, 2013) e nesse sentido se alinham com os objetivos dos serviços ecológicos prestados pela infraestrutura Verde, principalmente os relacionados ao manejo da água da chuva.

Assim, foram desenvolvidas as tipologias de MPM de águas pluviais, tais como canteiro pluvial, biovaleta, jardim de chuva e pavimento permeável. Por outro lado temos as árvores que numa cidade formam a floresta urbana, imprescindíveis na IV, pois têm funções ecológicas altamente significantes (HERZOG, 2010).

Os jardins de chuva consistem em um método de gestão de águas pluviais que dirigem as águas oriundas de telhados ou demais áreas pavimentadas a uma depressão topográfica (Figura 4). Essa depressão é formada por vegetação e solo alterado com compostos que aumentam a sua porosidade e infiltração no local, enquanto micro-organismos e plantas ajudam a remover poluentes originados do escoamento superficial (City of Portland Stormwater Management Manual, 2016). Os canteiros 
pluviais (Figura 5) são jardins de chuva em dimensões compactas que podem ser projetados junto às ruas, residências ou edifícios a fim de receber água do escoamento superficial de áreas impermeáveis (Portland, 2016).

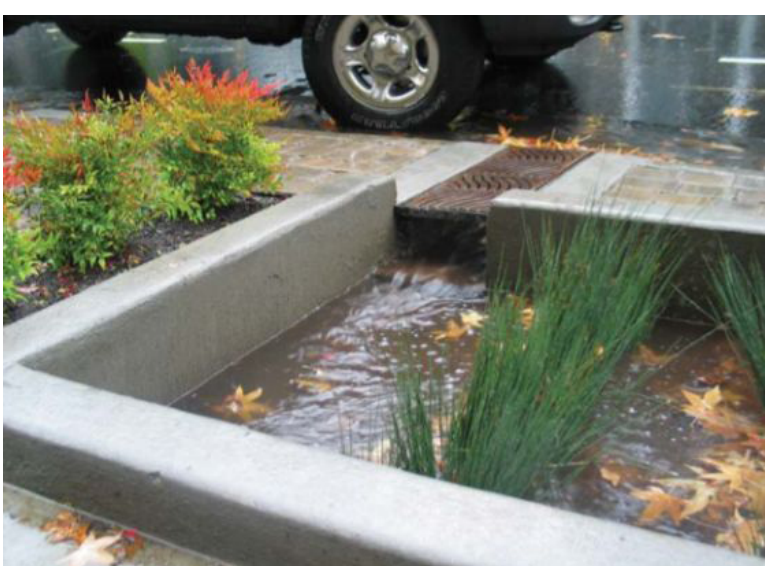

Figura 4 - Jardim de chuva em corte no meio fio. Fonte: Portland, 2016

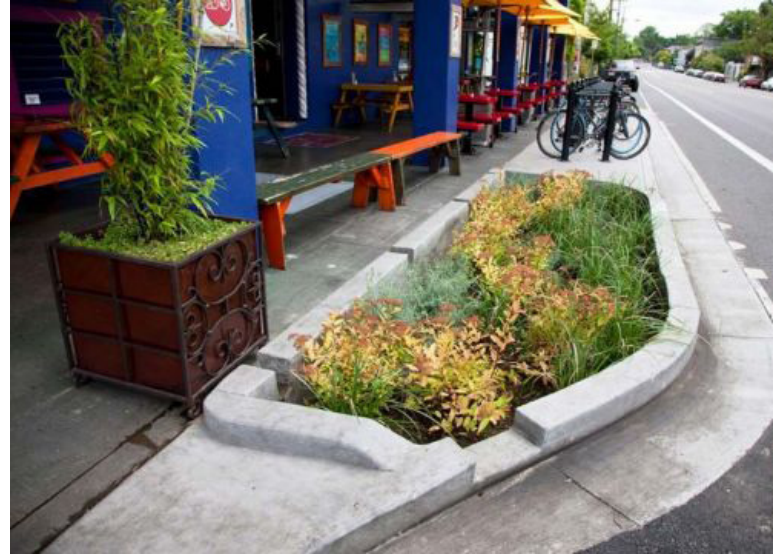

Figura 5 - Canteiro Pluvial em Potland. Fonte: Portland, 2016

Já as biovaletas (Figura 6) são depressões lineares preenchidas com vegetação, solo e elementos filtrantes com a finalidade de limpar as águas de chuva e ao mesmo tempo aumentar o seu tempo de escoamento, redirecionando-o para o jardim de chuva ou outros sistemas de retenção e detenção de águas (Portland, 2016). Em geral, essa tipologia é indicada para reter escoamentos de água das ruas e estacionamentos e podem ser instaladas dentro da via, entre o meio fio e a calçada (CORMIER; PELLEGRINO, 2008). Por outro lado, o pavimento permeável (Figura 7) é um tipo de pavimento que permite a passagem da água da chuva e derretimento de neve. São indicados para o controle da produção do escoamento superficial do próprio sistema viário (SUZUKI et. al., 2014).

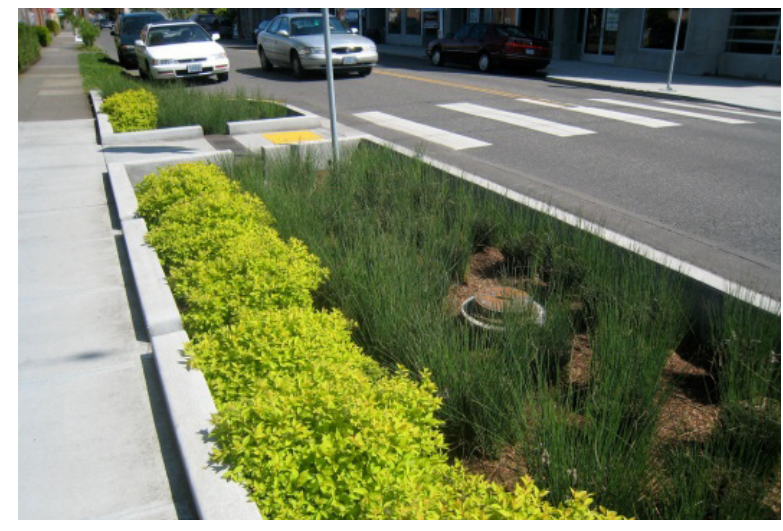

Figura 6 - Biovaleta em Portland Estados Unidos. Fonte: Portland (2016)

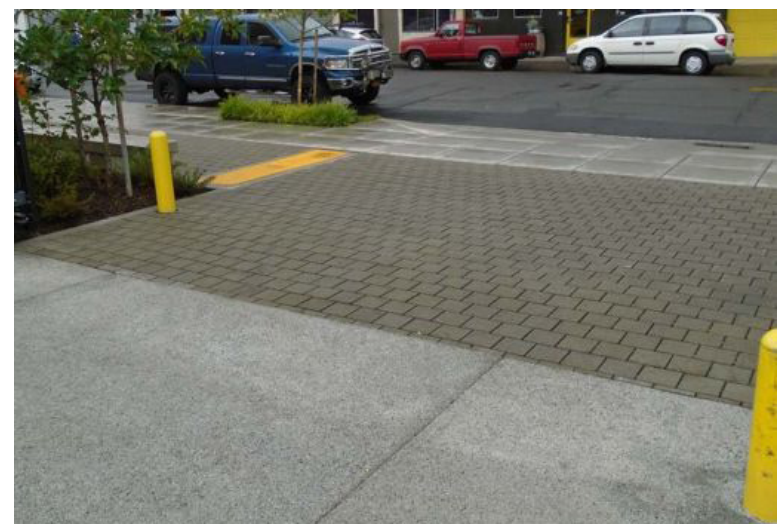

Figura 7 - Pavimento permeável.

Fonte: Portland (2016) 


\section{Arborização Urbana}

A floresta urbana é um dos elementos mais importantes da Infraestrutura Verde, ela compreende o somatório de todas as árvores de uma cidade. A mesma traz diversos benefícios para o ambiente, como a elevação da umidade relativa do ar e barreira à velocidade excessiva de ventos, desconfortáveis aos usuários do espaço público em questão (MARUYAMA, 2013). A área verde arborizada de uma cidade também colabora para diminuir a temperatura do ar e assim ajudar a reduzir os efeitos das ilhas de calor. Outro benefício importante das árvores dentro de uma IV é o auxílio na infiltração da água no solo, diminuindo o escoamento superficial. Para um planejamento adequado da arborização é preciso levar em itens como consideração: o porte, vida útil, a adaptabilidade ao clima, velocidade de crescimento, características das raízes, tipo de floração e resistência às pragas e doenças.

\section{Metodologia de análise adotada}

No intuito de sugerir a IV na área de estudo e realizar proposições envolvendo a rota cicloviária, foram necessárias análises englobando os seguintes tópicos referentes ao espaço viário: segurança, infraestrutura e arborização.

\section{Segurança viária}

Para o item segurança viária foram analisados: diferença de velocidade entre bicicletas e veículos motores, volume de tráfego de veículos, tipo de tráfego de veículos e existência de estacionamento lateral, para verificar necessidade de implantar ciclovia, ciclofaixa ou se é possível o compartilhamento do espaço por auto/bicicleta.

Sorton e Walsh (1994) indicam em seu trabalho uma maneira de avaliar o nível de segurança viária dos ciclistas, que os autores relacionam ao nível de tolerância ao conforto no trânsito. Deve-se fazer a verificação do volume aproximado na hora de pico (VAHP) e dividi-lo pelo número de faixas veiculares. No caso de pista dupla é aceito o percentual de 50/50. Acrescentamos aos critérios estabelecidos por Sorton e Walsh à necessidade de qual infraestrutura cicloviária implantar (Tabela 01). 


\begin{tabular}{c|c|c}
\hline Volume por faixa (volume/faixa/hora) & Nível de conforto no trânsito & Infraestrutura cicloviária \\
\hline$<50$ & $\mathrm{~A}$ & Compartilhamento bicicleta/auto \\
\hline$\geq 50 \mathrm{a} \leq 150$ & $\mathrm{~B}$ & Ciclofaixa \\
\hline$\geq 151 \mathrm{a} \leq 250$ & $\mathrm{C}$ & Ciclofaixa \\
\hline$\geq 251 \mathrm{a} \leq 350$ & $\mathrm{D}$ & Ciclovia \\
\hline$\geq 351 \mathrm{a} \leq 450$ & $\mathrm{E}$ & Ciclovia \\
\hline$>450$ & $\mathrm{~F}$ & Ciclovia \\
\hline
\end{tabular}

Tabela 1 - Segurança na via e infraestrutura cicloviária. Fonte: Sorton; Walsh (1994) e adaptado pelas autoras (2016)

Aos níveis de conforto no trânsito mais altos, associamos as infraestruturas cicloviárias que possuem maior interação entre ciclista e veículo. Aos níveis baixos relacionamos a ciclovia, por ela proporcionar maior grau de segurança. Para a estimativa do volume de veículo por faixa no período de uma hora foi feito contagem veicular, onde utilizamos o método da CE - Companhia de Engenharia de Tráfego de São Paulo (1982). Segundo este método, esta contagem deve ser feita em dia de semana de terça a quinta-feira, em horário de pico, em condições climáticas favoráveis para o ciclista e o dia da visita não pode ser próximo a feriado. Foram feitas contagens em períodos de 20 minutos e expandidos para 1 hora.

\section{Infraestrutura cicloviária}

A seguir apresentaremos as dimensões mínimas de calçadas e canteiros centrais para comportar ciclovias dentro de um projeto de IV. Tal proposta incluirá espaço para bicicleta e pedestre em passeio permeável, biovaleta, jardim de chuva ou canteiro pluvial e faixa para arborização viária, sempre que possível. As dimensões de calçada e canteiro consideram as recomendações da NBR 9050 (2004) para faixa de pedestre, Mascaró (2005) para plantio de árvore e as dimensões recomendadas para ciclovia e ciclofaixa por Mascaró (2005); Gondin (2010); Ministério das Cidades (2007), ANTP (2007) e GEIPOT (2001). A ciclovia pode ser implantada em canteiro central, junto à calçada ou no bordo da faixa de rolamento. A Tabela 2 indica as dimensões recomendadas para canteiro central e calçada com ciclovia bidirecional e unidirecional. 


\begin{tabular}{c|c|c|c|c|c|c|c}
\hline & $\begin{array}{c}\text { Ciclovia } \\
\text { Bidirecional }\end{array}$ & $\begin{array}{c}\text { Ciclovia } \\
\text { Unidirecional }\end{array}$ & $\begin{array}{c}\text { Árvore } \\
\text { Canteiro } \\
\text { pluvial }\end{array}$ & $\begin{array}{c}\text { Faixa de } \\
\text { pedestre }\end{array}$ & $\begin{array}{c}\text { Canteiro } \\
\text { separador } \\
\text { (Canteiro } \\
\text { Pluvial) }\end{array}$ & $\begin{array}{c}\text { Contenções } \\
\text { laterais de } \\
\text { meio-fio }\end{array}$ & Largura \\
\hline Calçada & $2,50 \mathrm{~m}$ & - & $1,0 \mathrm{~m}$ & $1,50 \mathrm{~m}$ & - & $0,40 \mathrm{~m}$ & $5,40 \mathrm{~m}$ \\
\hline $\begin{array}{l}\text { Canteiro } \\
\text { central A }\end{array}$ & - & 2,40 & $1,0 \mathrm{~m}$ & - & $0,75 \mathrm{~m}$ & $0,40 \mathrm{~m}$ & $4,85 \mathrm{~m}$ \\
\hline $\begin{array}{l}\text { Canteiro } \\
\text { central B }\end{array}$ & - & 2,40 & $1,0 \mathrm{~m}$ & - & $1,50 \mathrm{~m}$ & $0,60 \mathrm{~m}$ & $5,50 \mathrm{~m}$ \\
\hline $\begin{array}{c}\text { Canteiro } \\
\text { central C }\end{array}$ & - & 2,40 & $2,50 \mathrm{~m}$ & - & $1,50 \mathrm{~m}$ & $0,60 \mathrm{~m}$ & $7,00 \mathrm{~m}$ \\
\hline
\end{tabular}

Tabela 2 - Ciclovia em canteiro e calçada. Fonte: Autoras (2016)

Podem-se notar nas figuras 8, 9 e 10 ilustrações com as seções dos canteiros centrais A, B e C, as quais explicitam as dimensões indicadas na tabela.

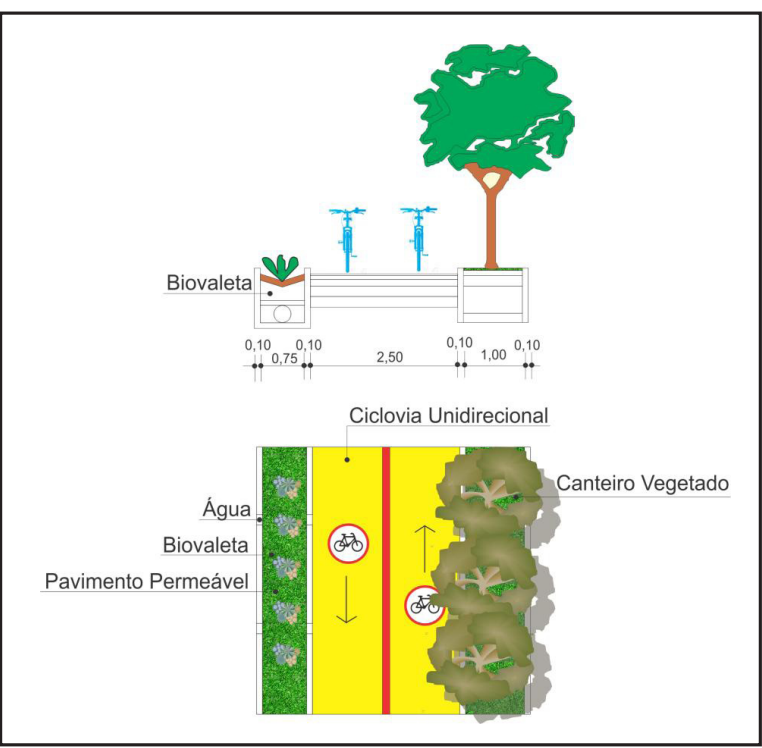

Figura 8 - Seção Mínima de Canteiro Central "A". Fonte: Autoras (2016)

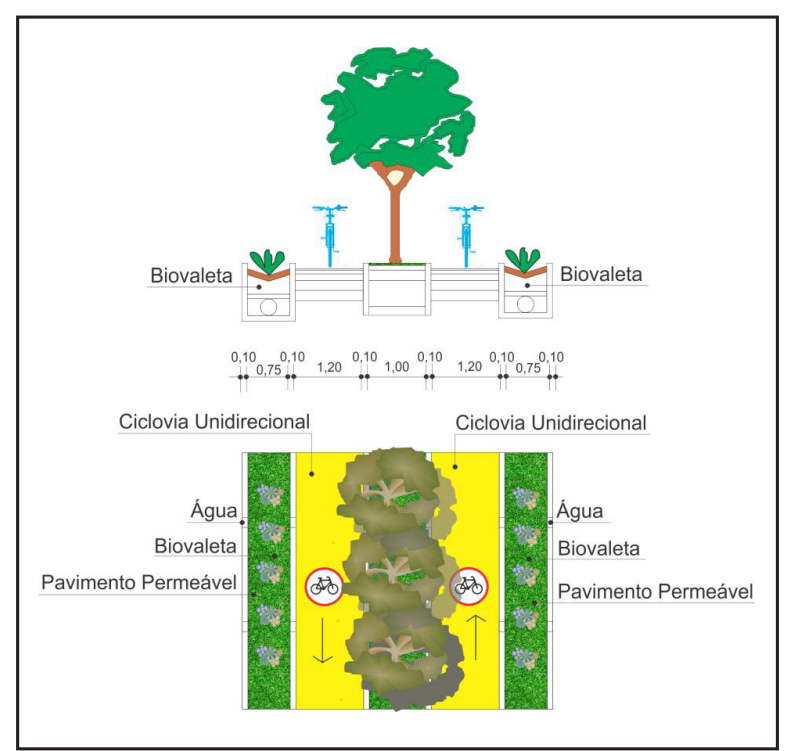

Figura 9 - Seção Mínima de Canteiro Central "B". Fonte: Autoras (2016) 


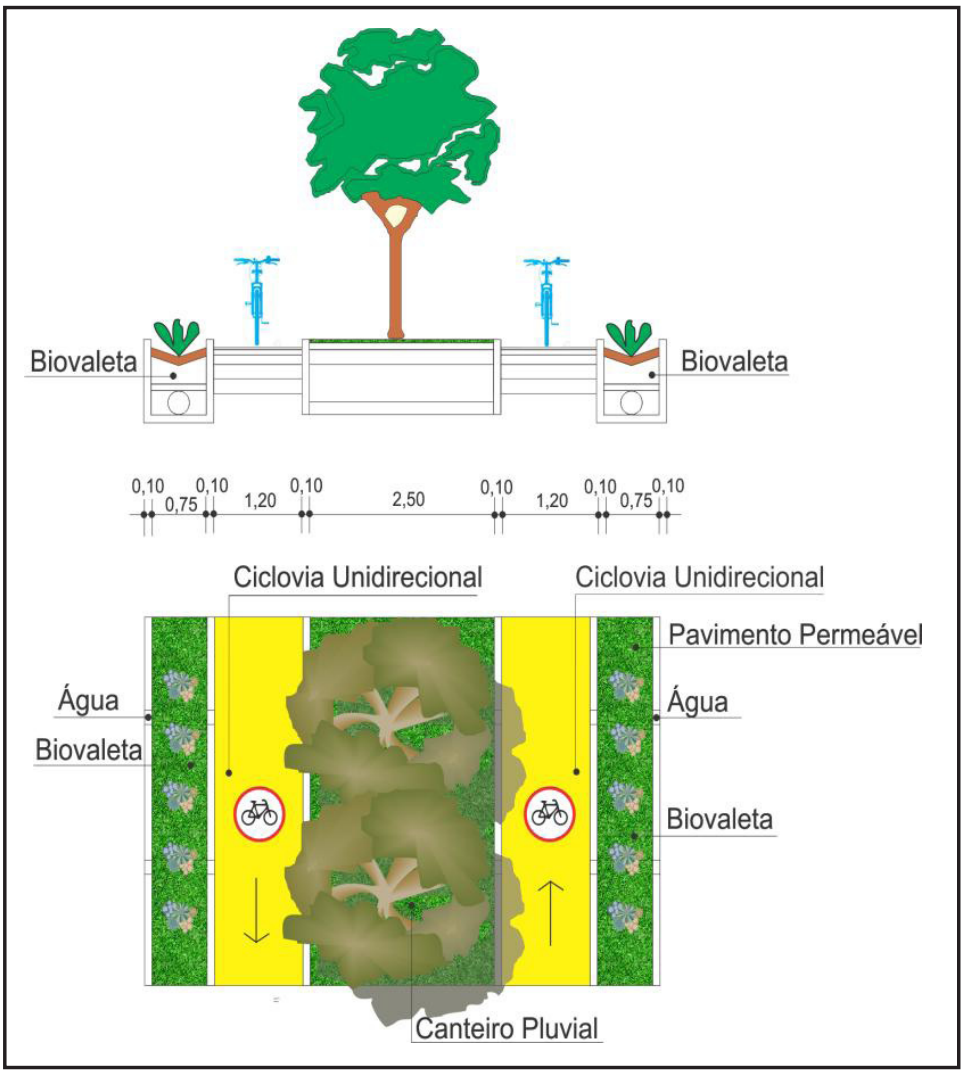

Figura 10 - Seção Mínima de Canteiro Central "C". Fonte: Autoras (2016)

A Tabela 3 indica as larguras para ciclofaixa unidirecional em canteiro e calçada. Há a opção de incluir árvore ou não, já que muitas calçadas em áreas urbanas consolidadas são estreitas.

\begin{tabular}{c|c|c|c|c|c|c}
\hline & $\begin{array}{c}\text { Ciclofaixa } \\
\text { unidirecional }\end{array}$ & $\begin{array}{c}\text { Árvore }+ \\
\text { canteiro } \\
\text { pluvial }\end{array}$ & $\begin{array}{c}\text { Faixa de } \\
\text { pedestre }\end{array}$ & $\begin{array}{c}\text { Canteiro } \\
\text { separador - } \\
\text { canteiro pluvial }\end{array}$ & $\begin{array}{c}\text { Contenção } \\
\text { lateral meio fio }\end{array}$ \\
\hline Calçada & $1,20 \mathrm{~m}$ & $1,0 \mathrm{~m}$ & $1,50 \mathrm{~m}$ & $0,75 \mathrm{~m}$ & 0,10 \\
\hline Calçada & $1,20 \mathrm{~m}$ & - & $1,50 \mathrm{~m}$ & $0,75 \mathrm{~m}$ & 0,10 & $3,55 \mathrm{~m}$ \\
\hline
\end{tabular}

Tabela 3 - Ciclofaixa unidirecional em calçada. Fonte: Autoras (2016)

\section{Arborização viária}

É pertinente mencionar que o projeto de arborização urbana precisa ocorrer de forma integrada ao desenho urbano (MARUYAMA, 2013). Algumas considerações são feitas 
com relação ao plantio nas calçadas: a área permeável do canteiro deve ser de $1 \mathrm{~m}^{2}$, há a necessidade de um distanciamento mínimo de $0,5 \mathrm{~m}$ entre o canteiro e o meiofio (pode aumentar de acordo com o porte da árvore) e a árvore deve ter uma altura mínima quando for plantada de $1,8 \mathrm{~m}$ a $2 \mathrm{~m}$ entre o canteiro e a base da copa (Ibidem).

De maneira geral, é possível arborizar em passeios com largura mínima de 2,5 m, contudo se nesta calçada existir rede aérea a espécie deve ser de pequeno porte. Caso contrário, o porte poderá ser médio ou grande (MASCARÓ, 2005).

O trabalho utilizou como método de análise da arborização a sensação térmica e a referente e à percepção do sombreamento do usuário pesquisador ao caminhar pelos espaços. Desta forma, as ruas foram enquadradas como áridas, semiáridas ou arborizadas de acordo com a constatação do grupo.

\section{Estudo de Caso}

Essa região faz parte de um trecho de enquadramento denominado "Trilha Norte- Sul" de uma pesquisa desenvolvida com subsídio da FAPESP/ SP com o título "Infraestrutura verde para a resiliência urbana às mudanças climáticas na cidade de São Paulo", cuja professora doutora Maria de Assunção Ribeiro Franco é a pesquisadora responsável. Pelo fato de interligar dois parques inseridos na "Trilha Norte-Sul", a possibilidade de implantação de uma Infraestrutura Verde nesta região apresenta-se como pergunta motivadora do presente artigo. A Figura 11 apresenta em destaque as vias analisadas. A seguir serão apresentadas análises referentes às bacias e talvegues, potencial de implantar a IV e segurança viária. 


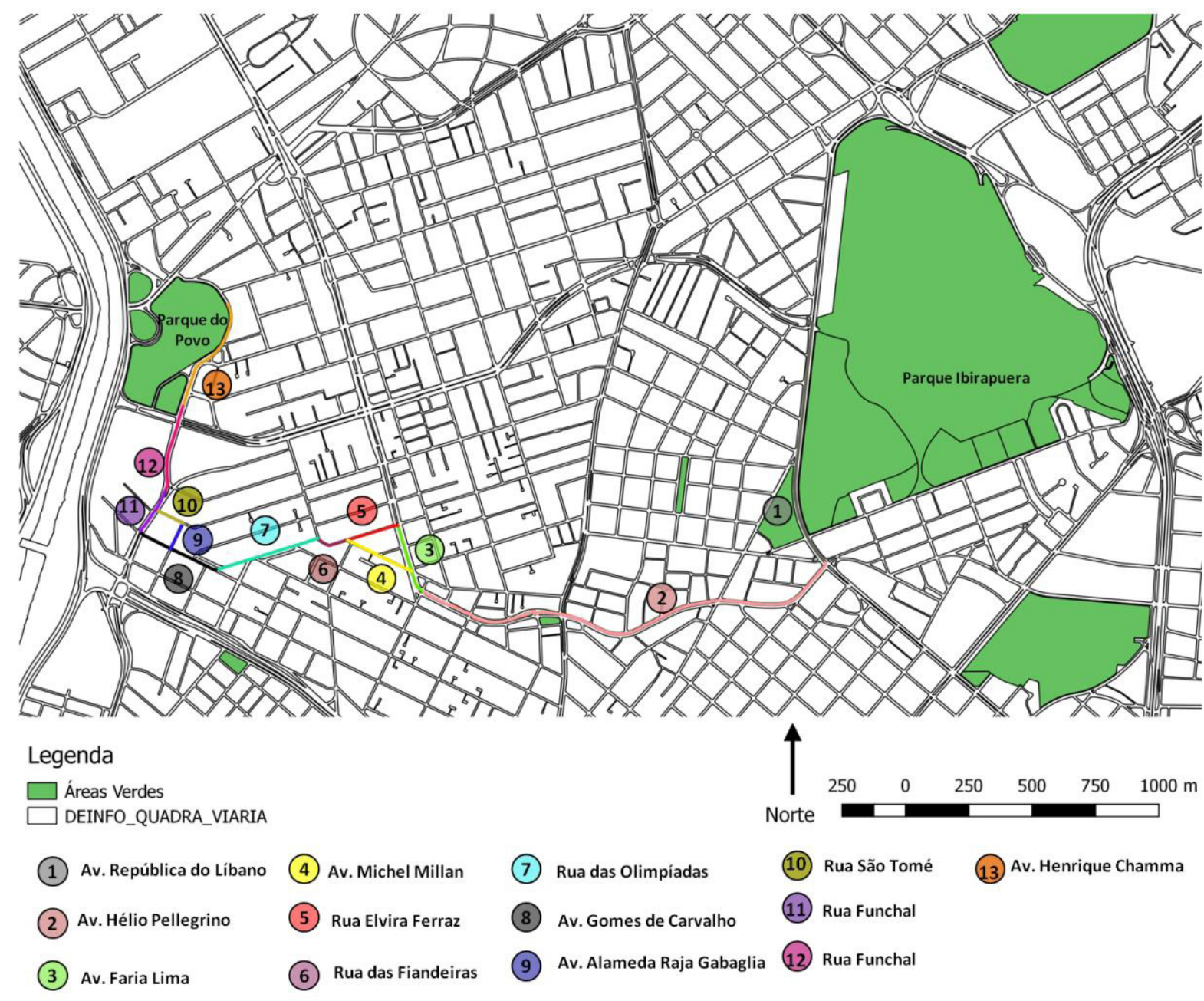

Figura 11 - Vias da área de estudo. Fonte: GEO SAMPA, modificado pelas autoras (2016).

\section{As bacias e seus talvegues contribuintes}

A rota cicloviária em estudo intercepta duas bacias, a do Córrego Sapateiro e a do Córrego Uberaba (Figura 12) e ambas deságuam no Rio Pinheiros. São pertinentes algumas ponderações no trecho em questão, com relação à drenagem urbana. Trata-se de uma região com altas taxas de impermeabilização do solo e as vias são pavimentadas com asfalto cujo coeficiente de escoamento superficial é 0,9 , ou seja, dez por cento da água infiltra e o restante escoa (SUZUKI et al., 2014). A ocupação do solo é alta, quase não há áreas verdes e permeáveis na região, as exceções mais consideráveis são o Parque do Povo e principalmente a grande mancha do Parque do Ibirapuera. 

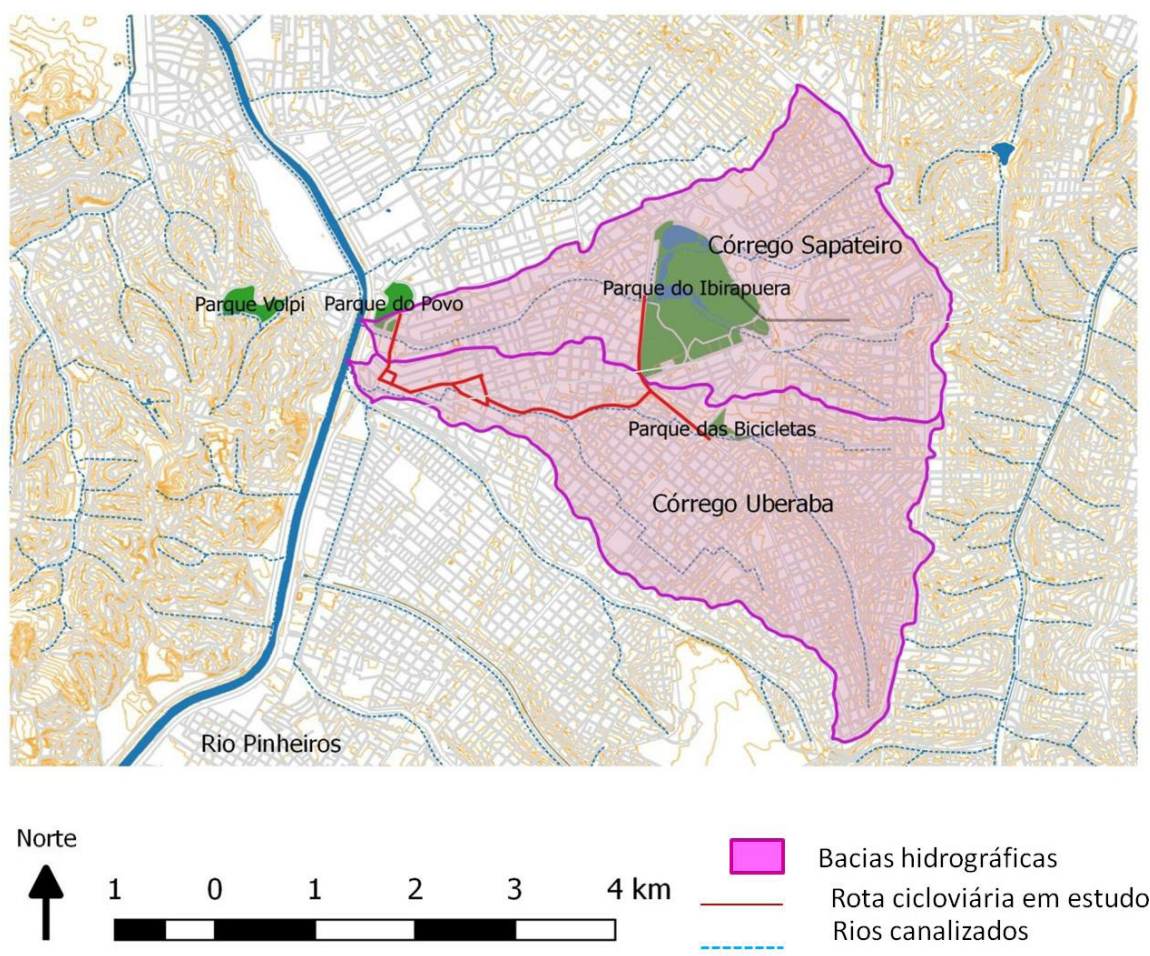

Figura 12 - Bacia hidrográfica da área de estudo. Fonte: Geo Sampa modificado pelas autoras (2016).

Outra constatação importante é a dos córregos estarem canalizados, sem possibilidade de serem abertos, pois a área apresenta urbanização consolidada e possui ocupação de alta densidade (torres). Por último, observa-se a rota cicloviária se encontrar em grande parte em fundo de vale, como se observa na Figura 14.

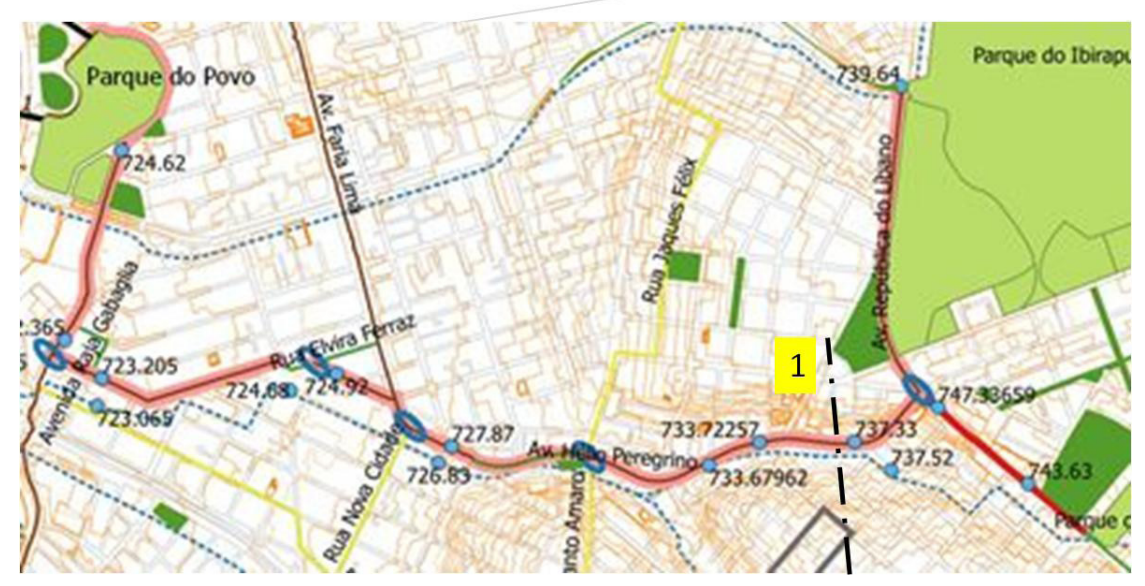

747

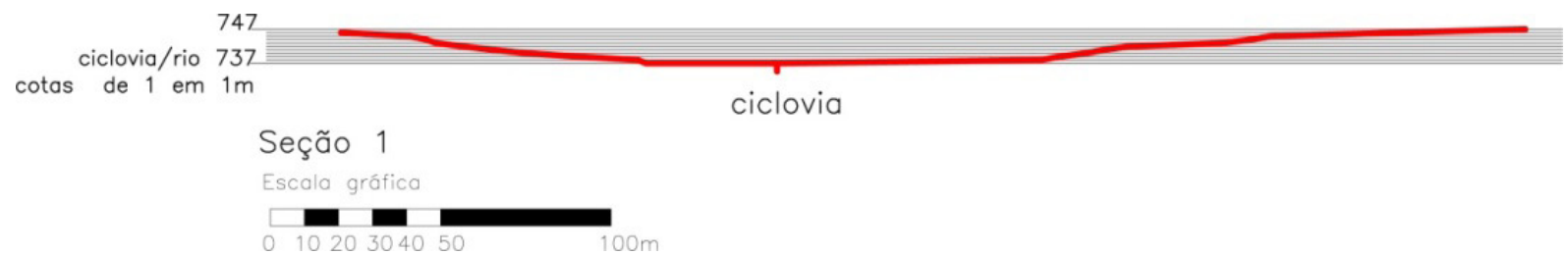

Figura 14 - Seções de terreno 1. Fonte: Geo Sampa modificado pelas autoras (2016). 
Tais constatações levam à análise de que a água que escoa para o fundo de vale se dirige em sua maioria para a rede de drenagem convencional que fica sujeito à sobrecargas em ocasiões de chuvas intensas, podendo acarretar em enchentes e alagamentos. Por tais motivos consideramos o trecho onde a rota cicloviária está em fundo de vale ser prioritário para receber intervenções de MPM de água pluvial e maximizar a arborização para aumentar a drenagem natural da área e diminuir a sobrecarga dos sistemas de drenagem convencionais.

\section{Análise de uma Infraestrutura Verde para a área de estudo}

A fim de melhor conhecer a área de estudo e identificar suas potencialidades quanto à implantação da IV, foram feitas visitas de campo. Nesta observou-se características de elementos como calçadas, canteiros centrais, ciclovias, ciclofaixas e a presença de arborização. Atentou-se também para questões relevantes como uso do solo, existência de polos geradores de tráfego, velocidade veicular das ruas e número de faixas de rolamento, fatores que também devem ser analisados durante o processo de elaboração de proposições e soluções para a área. Apresenta-se a Figura 15 com o nome de cada via visitada e os itens correspondentes avaliados.

\begin{tabular}{|c|c|c|c|c|c|c|c|}
\hline Nome da Via & $\begin{array}{l}\text { Infraestrutura } \\
\text { Cicloviária }\end{array}$ & $\begin{array}{l}\text { Largura da } \\
\text { Calçada }\end{array}$ & $\begin{array}{l}\text { Largura da Ciclovia } \\
\text { ou Ciclofaixa }\end{array}$ & $\begin{array}{l}\text { Número de faixas } \\
\text { de rolamento }\end{array}$ & $\begin{array}{l}\text { Sentido } \\
\text { único/duplo }\end{array}$ & Arborização & $\begin{array}{l}\text { Velocidade } \\
\text { Veicular }\end{array}$ \\
\hline Avenida República do Libano & $\begin{array}{l}\text { Ciclovia em } \\
\text { canteiro }\end{array}$ & $4.00 \mathrm{~m}$ & $1.20 \mathrm{~m}$ cada via & 3 & Duplo & Boa & $50 \mathrm{~km} / \mathrm{h}$ \\
\hline Avenida Hélio Pellegrino & $\begin{array}{c}\text { Ciclovia em } \\
\text { canteiro }\end{array}$ & $3.40-2.70 \mathrm{~m}$ & $1.20 \mathrm{~m}$ cada via & 2 & Duplo & Boa e Regular & $50 \mathrm{~km} / \mathrm{h}$ \\
\hline Avenida Faria Lima & $\begin{array}{c}\text { Ciclovia em } \\
\text { canteiro }\end{array}$ & $3.90 \mathrm{~m}$ & $1.20 \mathrm{~m}$ cada via & 4 & Duplo & Boa e Regular & $50 \mathrm{~km} / \mathrm{h}$ \\
\hline Avenida Michel Milan & $\begin{array}{c}\text { Ciclofaixa em } \\
\text { calçada }\end{array}$ & $4.10-5.79 \mathrm{~m}$ & $1.20 \mathrm{~m}$ cada via & 3 & Único & Boa e Regular & $60 \mathrm{kmh}$ \\
\hline Rua Elvira Ferraz & $\begin{array}{l}\text { Ciclofaixa } \\
\text { Operacional }\end{array}$ & $2.00 \mathrm{~m}$ & $3.00 \mathrm{~m}$ & $\begin{array}{c}2+1 \\
\text { (estacionamento) }\end{array}$ & Único & Ruim & $30 \mathrm{~km} / \mathrm{h}$ \\
\hline Rua das Fiandeiras & $\begin{array}{c}\text { Ciclofaixa } \\
\text { Operacional }\end{array}$ & $2.00-3.00 \mathrm{~m}$ & $3.00 \mathrm{~m}$ & $\begin{array}{c}2+1 \\
\text { (estacionamento) } \\
\end{array}$ & Único & Ruim & $30 \mathrm{~km} / \mathrm{h}$ \\
\hline Rua das Olimpiadas & $\begin{array}{l}\text { Ciclovia em } \\
\text { canteiro }\end{array}$ & $4.10 \mathrm{~m}$ & $1.20 \mathrm{~m}$ cada via & 3 & Duplo & Boa e Regular & $50 \mathrm{~km} / \mathrm{h}$ \\
\hline Avenida Gomes de Carvalho & $\begin{array}{c}\text { Ciclovia em } \\
\text { canteiro }\end{array}$ & $4.00 \mathrm{~m}$ & $1.20 \mathrm{~m}$ cada via & 3 & Duplo & Boa e Regular & $50 \mathrm{~km} / \mathrm{h}$ \\
\hline Alameda Raja Gabaglia & $\begin{array}{c}\text { Ciclofaixa } \\
\text { Operacional }\end{array}$ & $2.00 \mathrm{~m}$ & $3.00 \mathrm{~m}$ & $\begin{array}{c}2+1 \\
\text { (estacionamento) }\end{array}$ & Único & Ruim & $30 \mathrm{~km} / \mathrm{h}$ \\
\hline Rua São Tomé & $\begin{array}{l}\text { Ciclofaixa } \\
\text { Operacional }\end{array}$ & $1.84-3.30 \mathrm{~m}$ & $3.50 \mathrm{~m}$ & 2 & Único & Ruim & $30 \mathrm{~km} / \mathrm{h}$ \\
\hline Rua Funchal & $\begin{array}{c}\text { Ciclovia em } \\
\text { canteiro }\end{array}$ & $3.00 \mathrm{~m}$ & $1.20 \mathrm{~m}$ (cada via) & 3 & Duplo & Regular & $50 \mathrm{~km} / \mathrm{h}$ \\
\hline Rua Chedid Jafet & $\begin{array}{c}\text { Ciclovia em } \\
\text { canteiro }\end{array}$ & $3.00 \mathrm{~m}$ & $1.20 \mathrm{~m}$ (cada via) & 3 & Duplo & Regular & $50 \mathrm{~km} / \mathrm{h}$ \\
\hline Avenida Henrique Chama & $\begin{array}{c}\text { Ciclovia em } \\
\text { canteiro }\end{array}$ & $3.52 \mathrm{~m}$ & $1.20 \mathrm{~m}$ (cada via) & 4 & Duplo & Regular & $50 \mathrm{~km} / \mathrm{h}$ \\
\hline
\end{tabular}

Figura 15 - Vias e itens correspondentes avaliados na visita de campo. Fonte: Autoras (2016). 
A visita iniciou-se na Avenida República do Líbano (Figura 11- Ponto 1) a partir do Portão 7 do Parque Ibirapuera. A calçada não apresenta obstáculos ao longo do percurso e o canteiro central, que mede $5.97 \mathrm{~m}$ possui ciclovia bidirecional (Figura 16). Percebeu-se grande utilização da ciclovia nessa avenida por ciclistas no horário de 10h30min em uma terça-feira e o uso do solo nessa região é marcado por serviços.

Na região do Parque das Bicicletas há apenas a ciclofaixa operacional que funciona aos domingos (Figura 16). Para haver a interligação entre a rota cicloviária e este parque a nossa proposta é implantar uma ciclovia no canteiro central, devido ao grande volume veicular desta avenida, incompatível com compartilhamento de bicicleta ou ciclofaixa. Para isso é preciso avançar sobre uma faixa de veículos. Isto ocorreria num trecho curto, de cerca de $670 \mathrm{~m}$ de extensão, então não traria um impacto muito grande ao trânsito da região. Mas traria um grande benefício aos usuários de transporte cicloviário. Sugere-se a implantação de canteiros pluviais e biovaletas ao longo de todo canteiro central dessa região e pavimento permeável nas calçadas e ciclovias.

Contornada pelo Parque do Ibirapuera e apresentando um canteiro central formado por árvores de copas largas com pouco espaçamento entre as mesmas, a Avenida República do Líbano é considerada a mais arborizada do percurso, propiciando aos pedestres a permanência e a contemplação da mesma. Por tais motivos, esta avenida caracteriza-se como arborizada.

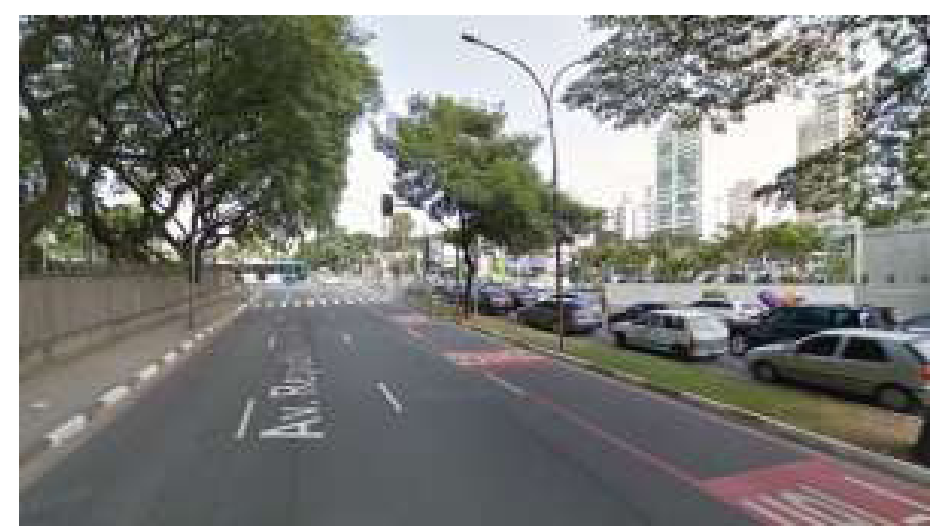

Figura 16 - Av. República do Líbano - Parque das Bicicletas. Fonte: Google Maps (2016).
A visita seguiu para a Avenida Hélio Pellegrino (Figura 11Ponto 2). Essa região é marcada pelo uso residencial, comercial e serviços. Possui calçada com largura total de $3.40 \mathrm{~m}$ sendo $1.20 \mathrm{~m}$ reservados para tráfego de pedestres e $2.20 \mathrm{~m}$ para equipamentos de serviço. A calçada diminui ao longo do trecho para $2.70 \mathrm{~m}$. O canteiro central mede $3.20 \mathrm{~m}$ e possui

ciclovia bidirecional com a presença de canteiro arborizado lateral em alguns trechos de $0.80 \mathrm{~m}$. Propõe-se o estreitamento das três faixas de via de tráfego, que hoje medem 3.30 cada, para $3.00 \mathrm{~m}$. Tal Avenida corresponde a maior porcentagem do per- 
curso em questão, observa-se que, a cobertura vegetal varia no decorrer da mesma. Há trechos com cobertura vegetal densa, ou seja, as árvores formam uma adequada proteção ao sol, tanto nas calçadas quanto no canteiro central. Há trechos no canteiro central em que o espaçamento entre as árvores é maior que vinte metros, gerando um espaço desértico e inibidor de vida, caracterizando então como semiárida. Propõe-se estreitar as faixas de via possibilitando a o aumento do canteiro central para instalação de biovaletas e mais árvores ao longo do percurso.

A análise de campo se direcionou depois para a Avenida Faria Lima (Figura 11- Ponto 3) que tem canteiro central de $3.95 \mathrm{~m}$ e possui ciclovia bidirecional. Os usos destacados foram em sua maioria serviços e empresarial e a via é composta por quatro faixas de rolamento de $3.20 \mathrm{~m}$ cada. Sugere-se a diminuição de três das faixas para $3.00 \mathrm{~m}$ destinados a veículo leve, restando $3.30 \mathrm{~m}$ para veículos pesados e os $0.55 \mathrm{~m}$ restantes podem ser direcionados para o alargamento do canteiro central e também para a instalação de biovaletas e arborização.

A visita prosseguiu para a Avenida Michel Milan (Figura 11- Ponto 4) a qual possui espaço cicloviário compartilhado com a calçada. Em alguns trechos a calçada mede $5,10 \mathrm{~m}$ sendo $2 \mathrm{~m}$ reservados para ciclofaixa bidirecional, $0.60 \mathrm{~m}$ de faixa verde e os outros $2.50 \mathrm{~m}$ restantes para a circulação de pedestres. Sugerimos o alargamento da ciclofaixa para $2.40 \mathrm{~m}$ bem como da faixa verde para $1.00 \mathrm{~m}$. O espaço restante de $1.70 \mathrm{~m}$ seria reservado para tráfego de pedestres, com $1.20 \mathrm{~m}$, dividido da ciclofaixa por biovaleta de $0.50 \mathrm{~m}$. Percebeu-se a incidência de uso residencial na região.

Em outros trechos da mesma avenida a configuração muda, onde se tem uma calçada de $5,79 \mathrm{~m}$ sendo $2.40 \mathrm{~m}$ de ciclofaixa bidirecional, $0.87 \mathrm{~m}$ de faixa verde e $2.52 \mathrm{~m}$ reservados para o tráfego de pedestres. Propõe-se o alargamento da faixa verde para $1.00 \mathrm{~m}$ com a instalação de arborização e redução do espaço de pedestres para 1.20, sendo os $0.50 \mathrm{~m}$ destinados à implantação de biovaletas. A Rua Michel Millan, logo na sua intersecção com a Avenida Brigadeiro Faria Lima, é formada por uma ciclovia completamente árida, ou seja, com uma calçada sem cobertura vegetal. Entretanto, na parte medial desta mesma rua, nota-se uma adequada presença arbórea que incentiva o ciclismo nesta porção, sendo definida por semiárida.

Seguindo o percurso, visitou-se a Rua Elvira Ferraz (Figura 11- Ponto 5), composta por uma pista de três faixas de rolamento no primeiro trecho (sendo uma para estacionamento) e duas faixas no trecho seguinte em um único sentido. A rua possui ciclofai- 
xa operacional que pode ser utilizada apenas nos domingos das $7 \mathrm{~h}$ às $16 \mathrm{~h}$. Propõe-se a retirada de $2.40 \mathrm{~m}$ referentes à faixa de estacionamento e aproveitamento deste espaço para ampliação da calçada com implantação de canteiros pluviais e árvores. Destacam-se os usos de serviços e empresarial nessa área.

A análise teve continuidade na Rua das Fiandeiras (Figura 11- Ponto 6), que possui calçada com $2 \mathrm{~m}$ em alguns trechos e $3 \mathrm{~m}$ em outros. A rua possui ciclofaixa operacional que pode ser utilizada aos domingos das $7 \mathrm{~h}$ às $16 \mathrm{~h}$.

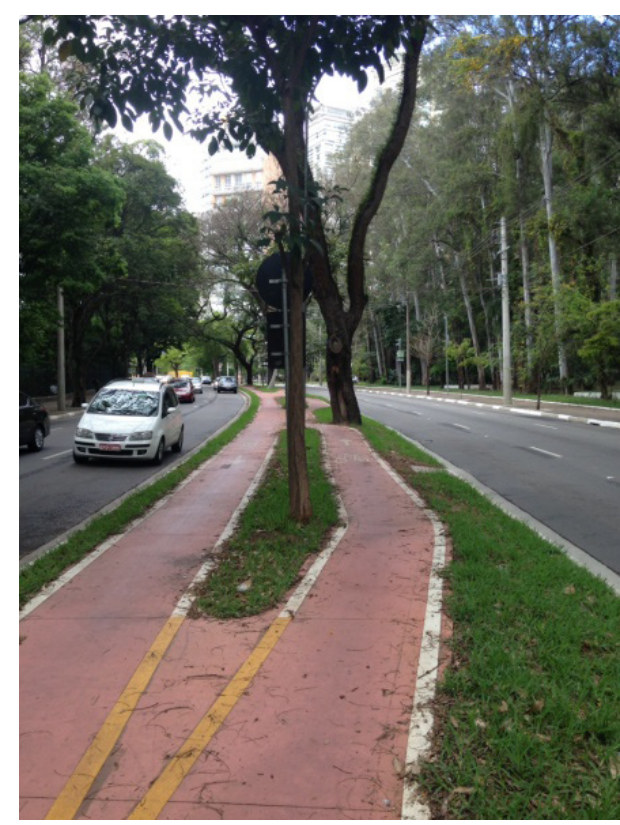

Figura 17 - Ciclovia em canteiro na Avenida República do Líbano. Fonte: Autoras (2016)

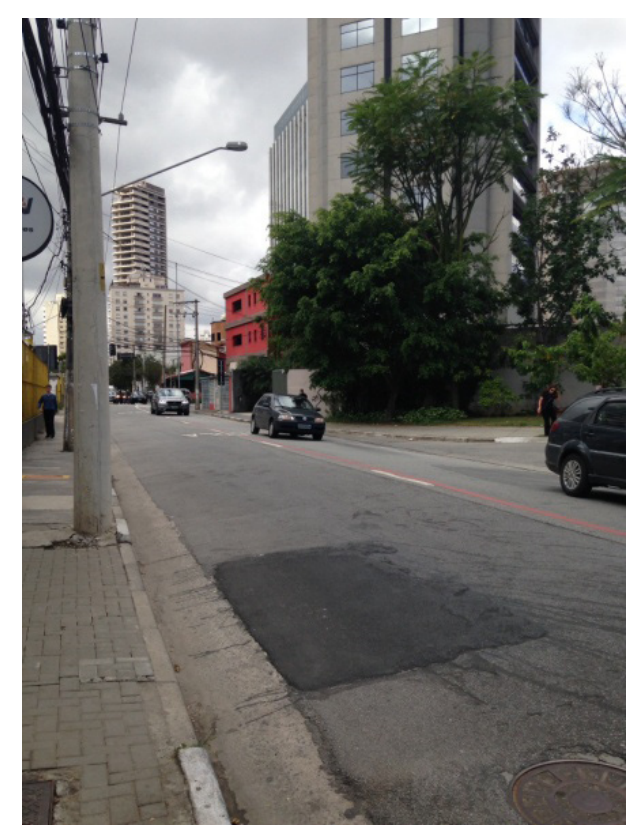

Figura 18 - Obstáculos na Rua Fiandeiras. Fonte: Autoras (2016)

Apresenta uso predominante o residencial e serviço, uma escola e um cursinho configuram-se como importantes polos geradores de tráfego na região. Como proposta, sugere-se retirar a faixa de estacionamento de $2.50 \mathrm{~m}$ e manter as duas faixas restantes para tráfego de veículos, com medida de $3.00 \mathrm{~m}$ cada. Os $2.70 \mathrm{~m}$ restantes podem ser aproveitados para a instalação de uma ciclovia na calçada, melhorando assim, a segurança dos ciclistas que fica comprometido na ciclofaixa existente devido ao alto tráfego de veículos. No setor onde há ciclovia notam-se apenas quatro árvores, sendo duas de pequeno porte e apenas uma de grande porte. Além da pouca quantidade, as existentes não são adequadas para prover conforto térmico nem propiciar sensação de sombreamento, oferecendo a sensação de aridez. 
O trajeto seguiu no sentido da Rua das Olimpíadas (Figura 11- Ponto 7), que apresenta calçada com largura de $4.10 \mathrm{~m}$, com faixa de serviço, e ciclovia no canteiro central composta por duas vias separadas por uma faixa verde. O uso predominante da avenida é serviço e comércio e destaca-se o Shopping Vila Olímpia como grande polo gerador de tráfego. Propõe-se a implantação de tipologias de biorretenção no canteiro central e plantio de árvores no canteiro central e nas calçadas.

Outra via analisada foi a Avenida Gomes de Carvalho (Figura 11- Ponto 8), que apresenta calçada de $4.00 \mathrm{~m}$ com faixas de serviço. Possui ciclovia bidirecional em canteiro central com faixas separadas por área verde e o uso do solo predominante nessa área é serviço e comércio. Sugere-se o também a instalação de biovaletas no canteiro central e canteiros pluviais entre a calçada e o meio fio.

Em relação à Avenida das Olimpíadas percebem-se calçadas largas com bom sombreamento, presença de ciclovias no canteiro central dotadas de vegetação de pequeno porte, ou seja, ineficazes ao sombreamento. A Avenida Gomes de Carvalho é uma continuação à Avenida Olimpíadas, desta forma, segue a mesma tipologia de arborização, em que as calçadas são mais arborizadas e os canteiros centrais, onde as ciclovias estão implantadas, possuem menor cobertura vegetal. Devido a características intermediárias entre a aridez e a arborização em ambas as vias, elas foram entendidas como semiáridas.

O percurso teve continuidade na Alameda Raja Gabaglia (Figura 11- Ponto 9), composta por uma pista com três faixas de rolamento em sentido único, sendo uma para estacionamento, além da existência de ciclofaixa operacional. Sugere-se a retirada de uma faixa de estacionamento de $2.40 \mathrm{~m}$ para alargamento das calçadas, bem como a implantação de tipologias de biorretenção como biovaletas e canteiros pluviais.

Analisou-se em sequência a Rua São Tomé (Figura 11- Ponto 10), que possui uma pista com duas faixas de rolamento em sentido único e ciclofaixa operacional ativada nos domingos das $7 \mathrm{~h}$ às $16 \mathrm{~h}$. A proposta é o estreitamento das duas vias, que hoje medem 4.00 , para $3.00 \mathrm{~m}$ cada sobrando assim, $2.00 \mathrm{~m}$ que podem ser utilizados para o alargamento de calçadas e instalação de canteiros pluviais ao longo do percurso. No trecho onde estão as ruas: Elvira Ferraz (Figura 11- Ponto 5), Alameda Raja Gabablia (Figura 11- Ponto 9) e São Tomé (Figura 11- Ponto 10) podem ser mantidas a ciclofaixa operacional de domingo. A justificativa é que há a alternativa da Rua Elvira Ferraz (Figura 11- Ponto 5) a ciclovia presente na Avenida Michel Milan (Figura 11- Ponto 4) e 
como alternativa para o trecho da Alameda Raja Gabablia (Figura 11- Ponto 9) e Rua São Tomé (Figura 11- Ponto 10) conta-se com a ciclovia da Rua Funchal.

Logo depois se deu continuidade à visita a campo nas ruas Funchal (Figura 11- Ponto 11) e Chedid Jafet (Figura 11- Ponto 12) que apresentam uma arborização moderada no canteiro central. A Rua Funchal, mais especificamente o trecho desta que é cortado pela ciclovia é formada por calçadas com raríssimas árvores, estima-se a presença de apenas quatro. No canteiro central deste trecho notou-se a existência de sete árvores bastante espaçadas, dentre as espécies observou-se palmeiras cujas copas são irrelevantes na tentativa de saciar a insolação, o grupo classificou esta via como árida. Essas duas vias apresentam ciclovia bidirecional no canteiro central. $\mathrm{O}$ uso predominante nessas ruas é o serviço e tem-se o Shopping JK Iguatemi na via Chedid Jafet como um polo gerador de tráfego.

Propõe-se na Rua Funchal o estreitamento das três faixas de tráfego, sendo uma faixa de 3.30 para tráfego pesado e as outras duas com $3.00 \mathrm{~m}$ para tráfego mais leve. Com essa redução, se ganha $1.20 \mathrm{~m}$ que pode ser aproveitado para a melhoria da ciclovia existente por meio da introdução de arborização e tipologias de biorretenção como canteiros pluviais e biovaletas. Semelhante à proposta da Rua Funchal, sugerese para a Rua Chedid Jaffet também o estreitamento das vias de tráfego existentes, sobrando $1.00 \mathrm{~m}$ para a implementação da ciclovia.

Por último, visitou-se a Avenida Henrique Chamma (Figura 11- Ponto 13). Esta conta com ciclovia bidirecional no canteiro central, mas ela não percorre toda a avenida e tem continuidade no interior do Parque do Povo. Como proposta sugere-se a implantação de ciclovia onde há continuação de canteiro central, a fim de proporcionar a uma rota que não desvie o ciclista da via. Percebeu-se grande uso da região por ciclistas e o uso evidente na área é o serviço. Esta Avenida apresenta canteiro central com arborização inexistente fazendo com que a ciclovia seja desprotegida da incidência solar. Sua calçada possui maior arborização, entretanto ainda necessita de melhorias, configurando-se como semiárida.

Mais adiante, na Rua Brigadeiro Haroldo Velozo (composta por três faixas de rolamento e sem canteiro central) que é continuação da Henrique Chamma, propõe-se a retirada de uma faixa de estacionamento de $2.40 \mathrm{~m}$ e estreitamento das outras vias, uma para $3.30 \mathrm{~m}$ destinada ao tráfego pesado e outra para $3.00 \mathrm{~m}$ para tráfego mais leve. Dessa forma, sobram $3.95 \mathrm{~m}$ que podem ser aproveitados para a instalação de ciclovia em calçada bem como biovaletas e canteiros pluviais para captação da água pluvial. 
Essas alterações propostas visam a implantação de Infraestrutura Verde na área de estudo, de maneira a beneficiar a mobilidade dos ciclistas que utilizam a região bem como a integração da cidade com a natureza e seus processos naturais. A Figura 19 ilustra a rota cicloviária e as propostas desta pesquisa, assim como as ciclovias desejáveis de existir para que haja interligação entre outras áreas importantes da cidade.

Existe uma travessia elevada tipo passarela com rampa que interliga a ciclovia da Marginal Rio Pinheiros com o Parque do Povo. Porém, não há conexão da Estação de trem Cidade Jardim com o parque para bicicleta, há somente por uma passarela de pedestres.

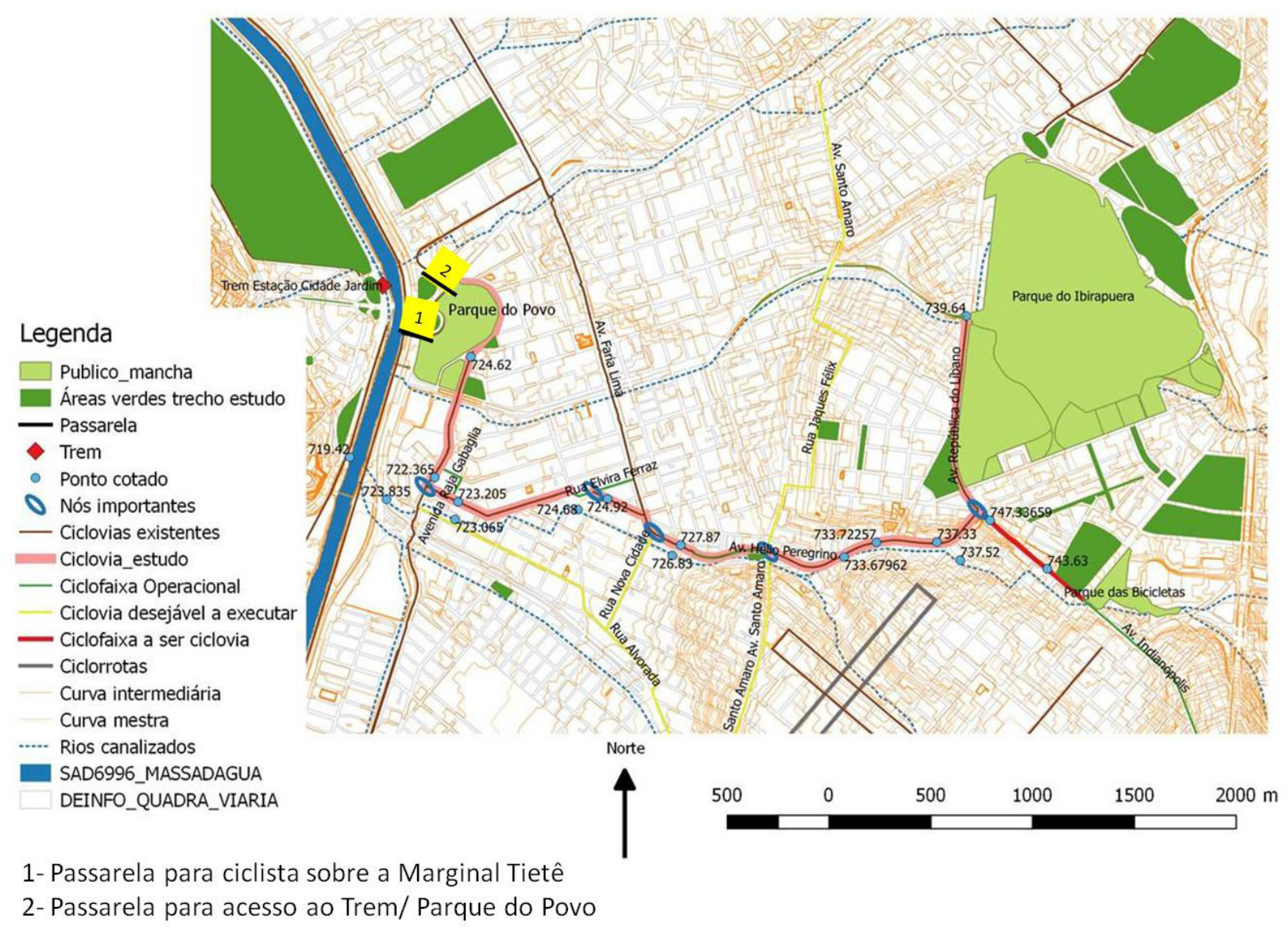

Figura 19 - Rotas cicloviárias na área de estudo. Fonte: Geosampa, modificado pelas autoras (2016).

A nossa sugestão é adaptar a passarela com canaleta para bicicleta, para que se possa usar a ligação intermodal entre o parque e a estação de trem, a qual é dotada de bicicletário. 


\section{Segurança Viária}

No trecho em análise existem áreas em que a rota cicloviária indicada pela CET/SP delimita espaço de bicicleta por ciclofaixa operacional que funciona apenas aos domingos. A nossa intenção na área é potencializar o uso da bicicleta em deslocamentos diários, não apenas aos finais de semana. O objetivo desta rota será: para lazer, com a interligação entre parques, e para trabalho e estudo, para acessar polos geradores de viagem da área. Para que esta rota possa ser usada diariamente é preciso primeiramente analisar a segurança viária para o ciclista.

Verificamos também que há dois trechos em que o espaço destinado à bicicleta é ciclofaixa operacional apenas para os domingos. Compreende as Rua Fiandeiras e Avenida Henrique Chamma. Nestes locais foi feita contagem veicular para verificar a necessidade de implantação de ciclovia ou ciclofaixa. Tal contagem se deu numa terça-feira, em outubro/16, no período do pico da manhã. Este período de pico na região estudada compreendeu o período de $7 \mathrm{~h} 00$ as $10 \mathrm{~h} 00$, que foi observado após visitas ao local. Em ambos locais a contagem foi feita por períodos de 20 minutos e depois expandida para $1 \mathrm{~h} 00$, para termos o volume VAHP. Foram envolvidos três pesquisadores. Na Rua Fiandeiras a contagem foi no período de 7 h30 às $7 \mathrm{~h} 50 . \mathrm{Na}$ Av. Henrique Chamma foi das $8 \mathrm{~h} 47$ às $9 \mathrm{~h} 07$, cumpre observar que nesta via o volume foi relativamente baixo porque o trânsito estava muito congestionado, quase parado. A Tabela 4 indica os dados coletados na contagem. Em relação à arborização as ruas foram percebidas como áridas, semiáridas e arborizadas.

\begin{tabular}{c|c|c|c|c|c}
\hline Local & $\begin{array}{c}\text { Veículo Leve } \\
\text { (Total) }\end{array}$ & $\begin{array}{c}\text { Veículo } \\
\text { pesado } \\
\text { (Total) }\end{array}$ & $\begin{array}{c}\text { Total de } \\
\text { veículos }\end{array}$ & $\begin{array}{c}\text { Número de } \\
\text { faixas }\end{array}$ & $\begin{array}{c}\text { VAHP } \\
\text { Volume por faixa (volume/ } \\
\text { faixa/hora) }\end{array}$ \\
\hline $\begin{array}{c}\text { Av. Henrique Chamma } \\
\text { - sentido bairro }\end{array}$ & 800 & 15 & 815 & 3 & 272 \\
\hline $\begin{array}{c}\text { Av. Henrique Chamma } \\
\text { - sentido centro }\end{array}$ & 474 & 33 & 507 & 3 & 169 \\
\hline Rua Fiandeiras & 822 & 04 & 826 & 2 & 413 \\
\hline
\end{tabular}

Tabela 4 - Contagem veicular e VAHP. Fonte: autoras (2016) 


\section{CONCLUSÕES}

A área em estudo interliga dois parques da cidade de São Paulo, portanto trata-se de um corredor com potencial de conectar duas áreas verdes significativas. A região se revelou com potenciais para a introdução da Infraestrutura Verde, embora esta seja altamente limitada pela exiguidade de espaço disponível.

A rota cicloviária como conexão entre os parques Ibirapuera e Parque do povo mostrou-se uma alternativa viável transporte, que se torna mais adequada quando associada a outros fatores da IV como arborização e melhores práticas de manejo das águas pluviais. Tais fatores colaboram para a melhoria das condições ambientais e, por consequência, na qualidade de vida da população. Os artifícios da IV ocasionam benefícios como a redução de temperaturas e da velocidade de escoamento da água bem como sombreamento e conforto térmico para usuários que caminham a pé ou utilizam a bicicleta.

Para sugerir modificações na rota cicloviária existente analisou-se a segurança viária. Após as verificações, destacou-se a Rua Fiandeiras a qual possui ciclofaixa operacional e onde foram identificados 413 veículos por faixa no período de uma hora. De acordo com a Tabela 3, para volume veicular maior ou igual a 251 veículos por faixa em uma hora é necessário instalar ciclovia, por isso propõe-se a instalação da mesma nesta via.

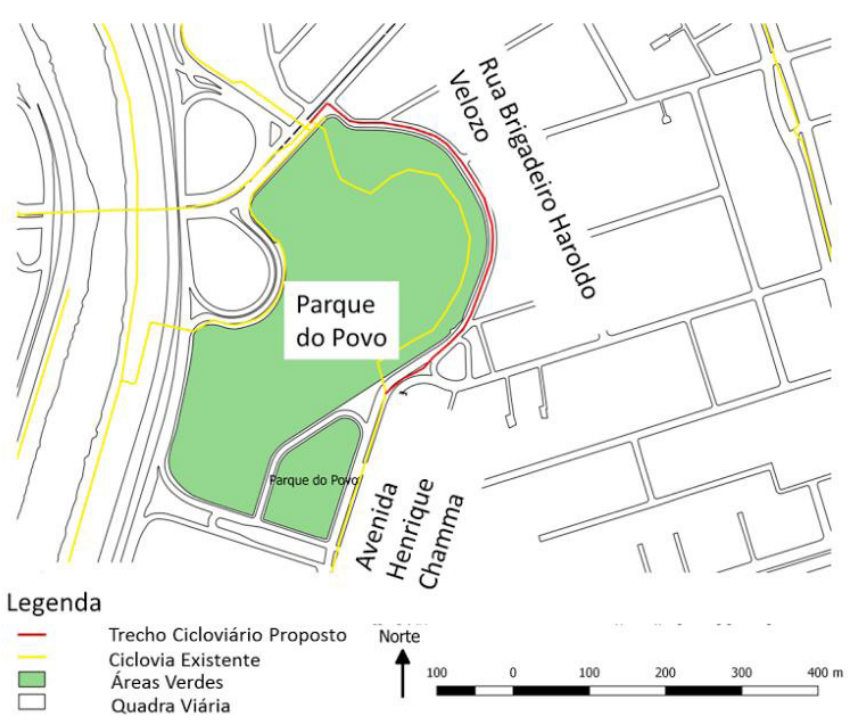

Figura 20 - Trecho cicloviário proposto nas Avenidas Henrique Chamma e Haroldo Velozo.

Fonte: GEOSAMPA, modificado pelas autoras (2016)
Na Avenida Henrique Chamma foram contabilizados 272 veículos no sentido centro e 169 veículos no sentido bairro. Consideramos esta ser a situação mais crítica, por envolver maior risco ao ciclista. Verificou-se que a ciclovia é interrompida em certo trecho da via com continuidade no Parque do Povo. Vê-se então a necessidade de continuação da ciclovia por toda a extensão da Henrique Chamma, assim como pela Rua Brigadeiro Haroldo Velozo, criando assim uma rota alternativa àquela que permeia o Parque (Figura 20). 
Ressalta-se que esta ciclovia deveria ser utilizada em dias de final de semana e dias úteis. Tal fato seria possível por meio da adaptação com canaleta para bicicletas na passarela que liga a Estação Cidade Jardim ao Parque do Povo, com a intenção de gerar uma ligação intermodal. Além disso, buscou-se ainda ampliar a permeabilidade da rota cicloviária existente por meio de algumas modificações viáveis, tais como a redução das faixas de rolamento para o tamanho mínimo bem como a retirada de estacionamento. Tais modificações possibilitam o alargamento de calçadas para instalação de canteiros pluviais, aumento do canteiro central para implementação do sistema cicloviário bem como melhoria da arborização.

De forma geral optou-se pela implantação de piso permeável em todas as calçadas e ciclovias do percurso. A Figura 21 ilustra uma proposta para uma via, a Av. Hélio Pellegrino, com a adoção da infraestrutura verde em questão. É necessário destacar que as intervenções propostas dependem de estudos mais avançados para serem de fato colocadas em prática. As vias da área de estudo apresentam mudanças de largura, rede elétrica e arborização existente. Portanto sugere-se para trabalhos futuros o estudo que envolva as seções mínimas, médias e máximas e particularidades de cada via.

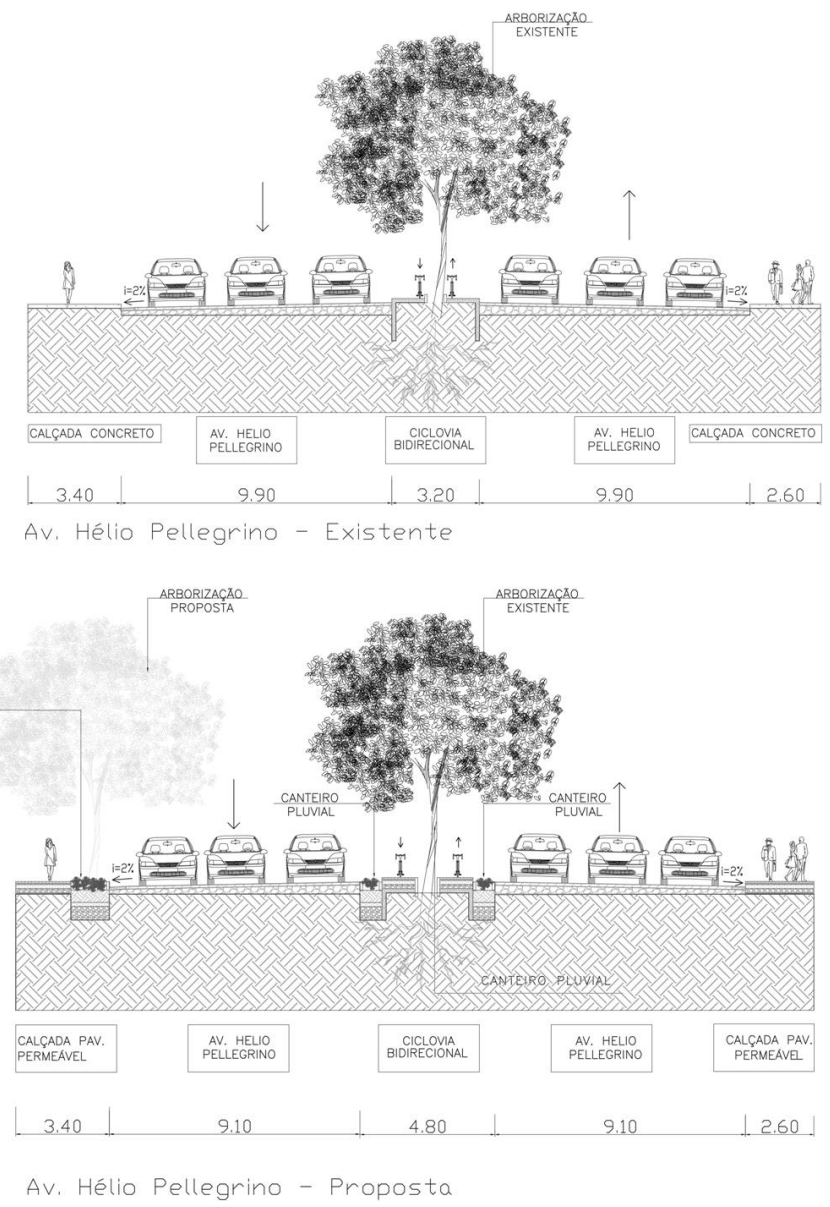

Figura 21 - Comparação entre seção existente e a proposta na Av. Hélio Pellegrino. Fonte: Autoras (2016) 


\section{REFERÊNCIAS BIBLIOGRÁFICAS}

AHERN, J.; PELLEGRINO, P.; BECKER, N. Infraestrutura verde desempenho, estética, custos e método. In: Lucia Maria Sá Antunes Costa; Denise Barcellos Pinheiro Machado (org.). Conectividade e resiliência: estratégias de projeto para a metrópole. Rio de Janeiro. Rio Books: PROURB, 2012.

ANTP - Associação Nacional de Transportes Públicos. Transporte Cicloviário. Volume 7 Série Cadernos Técnicos. 2007

ASSOCIAÇÃO BRASILEIRA DE NORMAS TÉCNICAS. NBR 9050 - Acessibilidade a edificações, mobiliário, espaços e equipamentos urbanos. Rio de Janeiro, 2004.

CITY OF PORTLAND. Stormwater Management Manual. August, 2016. Disponível em: < https://www.portlandoregon.gov/bes/64040 >. Acesso em: 07/03/17

COMPANHIA DE ENGENHARIA DE TRÁFEGO - CET. Boletim Técnico n 31. Pesquisa e Levantamentos de Tráfego. São Paulo, 184p., 1982.

CORMIER, Nathaniel S; PELLEGRINO, Renato M. Infraestrutura verde: uma estratégia paisagística para a água urbana. Paisagem e Ambiente: ensaios, São Paulo, v. 25 , p. $127-142,2008$.

GEIPOT - Empresa Brasileira de Planejamento de Transportes. Manual de Planejamento Cicloviário. Brasília, 2001.

GONDIM, Monica Fiuza. Ciclovias. Caderno de desenho, Rio de Janeiro, 2010. Disponível em: <http://www.solucoesparacidades.com.br/wpcontent/uploads/2010/01/24\%20\%20 BRASIL_Caderno\%20de\%20Desenho_Ciclovias.pdf>. Acesso em: 11 nov. 2016.

HERZOG, C. P. Infraestrutura verde: sustentabilidade e resiliência para a paisagem urbana. Revista Labverde $n^{\circ} 1$, pp. 92 - 115, 2010.

. Seção IV: Ambiente construído. Infra-estrutura verde para cidades mais sustentáveis. Secretaria do Ambiente. 2010. 
MARUYAMA, C. M. Análise de eixos viários na perspectiva do uso da bicicleta: o caso de Chapecó - SC. 2013. 172 f. Dissertacão (Mestrado em engenharia urbana) - Universidade Estadual de Maringá, Santa Catarina, 2013.

MARUYAMA, C.M.; SIMÕES, F. A. Arborização urbana e transporte cicloviário: o caso de Chapecó, SC. Revista dos Transportes Públicos - ANTP, ano $36,2^{\circ}$ quadrimestre, 2014.

MASCARÓ, J. L. Loteamentos Urbanos. $2^{\circ}$ ed. Porto Alegre: Masquatro Editora, 2005.

MINISTÉRIO DAS CIDADES. Coleção bicicleta Brasil: Programa Brasileiro de Mobilidade por Bicicleta. Ministério das Cidades: Brasília, 2007.

MOURA, N. C. B. Biorretenção tecnologia ambiental urbana para o manejo das águas da chuva. [s.l.] Tese (doutorado). Faculdade de Arquitetura e Urbanismo, Universidade de São Paulo, 2013.

PORTLAND, city. Stormwater Management Manual. 502p. 2016. Disponível em $<$ https://www.portlandoregon.gov/bes/64040>

SKANSI, M.M. et al. Warming and wetting signals emerging from analysis of changes in climate extreme indices over South America. Global and Planetary Change, v. 100, p. 295-307, 2013.

SORTON, A.; WASH, T. Bicycle stress level as a tool to evaluate urban and suburban bicycle compatibility. Transportation Research Record, 1438, p. 17-24, 1994.

SUZUKI, Carlos Yukio; AZEVEDO, Angela Martins; KABBACH, Felipe Issa Kabbach Júnior. Drenagem subsuperficial de pavimentos. Conceitos e dimensionamento. Oficina de Textos. São Paulo, 2014. $1^{\circ}$ edição.

TUCCI, C.E.M; ORSINI, L. F. Águas urbanas no Brasil: cenário atual e desenvolvimento sustentável. In: Brasil. Secretaria Nacional de Saneamento Ambiental. Gestão do território e manejo integrado das águas urbanas. Brasília: Ministério das Cidades, 2005. 